\title{
Structural Changes Induced by Potassium Dichromate in Renal Cortex of Adult Male Albino Rats and the Possible Protective Role of Selenium
}

\author{
ALSHYMAA O.H. AHMED, M.Sc.; HANAN E.L. MOKHTAR, M.D.; HEBA O.M. HELMY, M.D. and \\ SAMAA S. ABD EL-FATAH, M.D.
}

The Department of Anatomy \& Embryology, Faculty of Medicine, Zagazig University

\begin{abstract}
Background: Potassium Dichromate $(\mathrm{Cr})$ is a common environmental agent that has been considered potentially carcinogenic, making it an issue of major environmental and search concern.

Aim of Study: The aim of this study was to throw light on the possible structural changes in the renal cortex of adult male albino rats after administration of $\mathrm{Cr}$ and to elucidate the possibility of protection by selenium (Se) against the deleterious effects of $\mathrm{Cr}$.

Material and Methods: Thirty six adult male albino rats weighing 200-230g were divided equally into four groups as follow: Group I received balanced diet and tap water only; Group II received Se orally $0.25 \mathrm{mg} / \mathrm{kg}$ b.w/daily; Group III rats were received $\mathrm{Cr}$ orally $67 \mathrm{mg} / \mathrm{kg} /$ daily and Group IV rats were received oral $\mathrm{Cr}$ and $\mathrm{Se}$ at same previous doses. Animals were sacrificed on day 28 .
\end{abstract}

Results: The Cr-treated group showed damage of the renal cortex including capsule and renal interstitium. Masson's trichrome staining showed abundant collagen fibers. The expression of caspase- 3 in the cytoplasm showed strong positive immune reaction in group III. Biochemical results showed $\mathrm{Cr}$ induced significant increase in blood urea nitrogen (BUN), serum creatinine (SC) and uric acid (UA). While morphometric measurement indicated that $\mathrm{Cr}$ induced a statistical significant decrease in rat body weight and diameter of glomeruli when compared with other groups. The Cr-treated group also showed a statistical significant increase in kidney weight, surface area of Bowman space, diameter of the convoluted tubules, area percentage of collagen fibers and expression of caspase-3. Meanwhile, administration of Se showed some protection against the toxic effect of $\mathrm{Cr}$ on renal cortex.

Conclusion: It is suggested that administration Se moderately improves the deleterious histological and biochemical changes induced by $\mathrm{Cr}$ on renal cortex.

Key Words: Renal cortex - Potassium Dichromate - Albino rats-Caspase-3-Selenium.

Correspondence to: Dr. Samaa S. Abd El-Fatah, E-Mail: samaasalah12@yahoo.com

\section{Introduction}

THE wide spread of heavy metal in the environment is one of the main causes of the toxicity of the human organ system. Cr, lead, cadmium, mercury and arsenic and their organic compounds are the most toxic metal in the environment [1]. Cr is a naturally occurring heavy metal found in volcanic dust, rocks, soil as well as plants and animals [2].

The most prevalent and stable forms of chromium in the environment are Hexavalent Chromium $\mathrm{Cr}$ (VI) which can cross cellular membranes. It is an enormous environmental toxin and pollutant that arises from cigarette smoke, automobile emissions and sites of incineration [3]

The most toxic form of $\mathrm{Cr}$ (VI) is Potassium Dichromate. Potassium dichromate $(\mathrm{K} 2 \mathrm{Cr} 2 \mathrm{O} 7)$ is a chemical compound widely used in chemical industry, metallurgy, chrome plating, surgical prostheses, stainless steel industries; textile manufacture, wood preservation and cooling systems [4] $\mathrm{Cr}$ resulted in oxidative stress and has been demonstrated to induce nephrotoxicity in humans and animals. The wide environmental distribution of these agents leads to an increase interest of preventive effects of its adverse effects [5].

Anti-oxidants provide protection against degenerative diseases including cancer, Alzheimer's diseases and coronary heart diseases [6]. Se is an essential micronutrient for human and animal health due to its capabilities to support antioxidant defence systems. It is required for multiple actions related to health, performance and disease prevention. It is an essential component of many enzymes including glutathione peroxidase (GPx) and thioredoxine reductase involved in antioxidant defense, regula- 
tion of reproduction, growth, development and many other physiological functions protecting cells from oxidative damage [7]. Therefore, the present study was aimed to evaluate possible ameliorating role of Se against the deleterious effects of $\mathrm{Cr}$ on renal cortex.

\section{Patients and Methods}

\section{Animals:}

Thirty six adult healthy male albino rats 3-6 months of age each weighed 150 to $200 \mathrm{gm}$. They were obtained from the animal house unit in the Faculty of Medicine, Zagazig University from March 2017 - Sep. 2017. All animals were housed in environmentally controlled rooms, in wire mesh cages. They were kept under good hygienic conditions and fed on a balanced diet and tap water for two weeks before study. The experiment was conducted in accordance with the guidelines for the care and use of research animals. All efforts were made to minimize the suffering of the animals.

\section{Drugs used:}

$\mathrm{Cr}$ and SE were purchased from El-Gomhoria Company for Chemical and Medical Trading and Sigma-Aldrich Chemical Company respectively.

\section{Experimental design:}

At the beginning of experiment, the animals were weighed to estimate the initial body weight in different studied groups using a sensitive digital balance. Later, these animals were randomly divided into four groups with nine animals for each. Group I (control group): Animals were gavaged only with balanced diet and tap water. Group II (Se-treated group): Animals were given daily dose of sodium selenite $(0.25 \mathrm{mg} / \mathrm{kg} \mathrm{b.w}$, dissolved in distilled water) [8]. Group III (Cr-Treated Group): each was given daily dose of $\mathrm{Cr} 700 \mathrm{ppm}$ equivalent $67 \mathrm{mg} / \mathrm{kg}$ bw, dissolved in approximately $96 \mathrm{ml}$ tap water [9]. Group IV (Cr and Se-Treated Group): Animals were gavaged orally with $\mathrm{Cr}$ followed by Se by the same manner mentioned above once daily for 4 weeks [10]. At the end of experiment, the body weight was again assessed using the same sensitive digital balance to estimate the final body weight of rats in different studied groups. Venous blood samples were collected from retro-orbital plexues of each rat for assaying SC, BUN and UA levels. Animal were anaesthetized with intraperitoneal injection of phenobarbitone then sacrificed. The abdominal cavities of animals were opened; both kidneys were immediately dissected, removed out, grossly inspected to assess any gross abnormalities and washed with cold normal saline. Each kidney was weighed by sensitive digital balance and processed for light microscope examination and morphometeric studies.

Biochemical estimation of blood urea nitrogen $(B U N)$, serum creatinine (SC) and uric acid $(U A)$ : The collected blood was centrifuged and plasma fraction was separated at clinical pathology lab., veterinary medicine, Zagazig University.

Preparation for light microscopy: Each kidney was cut into two halves across the renal pelvis along its longitudinal axis to expose cortex, medulla and papilla. The specimens were immediately immersed in $10 \%$ formol saline for 48 hours to be processed and embedded in paraffin according to Bancroft and Layton [11]. The tissue sections of 5 m mere stained with haematoxylin and eosin, Masson's trichrome, examined and photographed under light microscope at histology Department, Zagazig University.

Preparation for Immunohistochemical study: were carried out on sections of the renal cortex using Caspase-3 [12,13] . Immuno histochemical staining resulted in dark brown colouration in antigen-containing cells. The prepared specimens were examined at histology Department, Zagazig University.

Morphometric studies and image analysis: Sections stained with haematoxylin and eosin (per 100 high power field), Masson's trichrome stain and immuno histochemical stain (per 400 high power field) were photographed and morphometrically analyzed by using Digimizer 4.3.2. Image analysis software (Med Calc Software bvba, Belgium) and NIH Image J (v1.50) image analysis software. Quantitative data were collected for 5 parameters: The diameter of glomeruli in renal interstitium; the area of Bowman's space of the renal corpuscles; The diameter of convoluted tubules; The area percentage of collagen fibers and The area percentage (\%) of caspase -3 expression. Five non-overlapping fields from five rat kidney sections were selected randomly and statically analyzed.

Statistical analysis: The results were computed on IBM Pc microprocessor by a statistical software package Epi-Info version 6.02 [14]. Quantitative data were expressed as mean \pm SD (Standard deviation). One way analysis of variance (ANOVA or F-test) was used for comparison of means of more than two groups. Unpaired student $t$-test was used to determine significant difference between initial and final body weight of each group. Least 
significance difference (LSD) test was used to find significance between each two studied groups. It was calculated at different probability values. $p$ value of $<0.05$ indicates significant results or of $<0.01$ indicate highly significant results.

\section{Results}

\section{Histological results:}

\section{Group I (control group):}

The renal cortex was surrounded by thin renal capsule. The renal cortex was formed of renal corpuscles and tubules. The cortical renal corpuscle consisted of a glomerulus containing tuft of capillaries and surrounded by visceral and parietal layers of Bowman's capsule with Bowman's space in between. The outer parietal layer was formed of flat cells while the inner visceral layer was closely related to the glomerular capillaries. The cortical renal tubules were formed mainly of proximal and distal convoluted tubules. Distal convoluted tubules had wider lumen than proximal convoluted tubules. They were lined by small cuboidal cells and eosinophilic cytoplasm. Proximal convoluted tubules had narrow lumen and lined by cuboidal cells and more eosinophilic cytoplasm (Figs. 1a, 1b).

Masson's trichrome-stained sections showed scanty collagen fibers in the renal capsule and in renal interstitium that surrounding the renal tubules, blood vessels and renal glomerulus. Less dense fibers around glomerular capillaries within the glomeruli were observed (Fig. 1c,1d).

Immunohistochemically, the sections of rat kidney of control group showed negative immune reaction for caspase-3 in the cytoplasm of most tubular cells and renal glomeruli (Fig. 1e).

\section{Group II (Se-treated group):}

Examination of H\&E, masson's trichrome and immunohistochemical stained sections of the selenium treated group revealed similar results as observed in the control group (Figs. 2a-e).

\section{Group III (Cr-treated group):}

In $\mathrm{Cr}$ treated group revealed massive destructive damage of the renal cortex if compared with other previous groups. Fatty cell infiltration and area of hemorrhage were demonstrated embedded within the capsule making it very thick. The capsule was separated from the renal cortex by wide space. Some atrophic renal glomeruli were observed in interstitial renal cortex (Fig. 3a). They appeared shrunken and degenerated with dilated Bowman's spaces. The parietal layer of renal corpuscle showed dark stained nuclei (Fig. 3b). In some areas, there were marked lobulated glomeruli with congested glomerular capillaries and wide bowman's spaces as well (Fig. 3c). However, some glomeruli were observed hypertrophied with narrow or greatly obliterated bowman's space at one side (Figs. 3d,e).

On the other hand, the distal convoluted tubules appeared dilated and showed areas of cellular loss with their sloughing into the lumens. Some tubular cells appeared with pyknotic nuclei (Fig. 3b). However, the proximal convoluted tubular cells displayed marked cytoplasmic vacuolation (Fig. $3 c$ ). Some renal cortical convoluted tubules showed deposition of acidophilic hyaline material while others showed deposition of cellular debris containing pyknotic nuclei in their lumens or with distorted cellular lining and dilated lumens (Figs. $3 e, f, g)$.

Moreover, there was loss of architecture of the renal interstitium with the presence of massive areas of both hemorrhage and mono-nuclear inflammatory cell infiltration. In addition, many small focal inflammatory areas around glomeruli and between the renal tubules were also observed. The blood vessels were congested with markedly thickened wall (Figs. 3d-g).

Masson's trichrome stained sections of the same group showed abundant collagen fibers located in the thick renal capsule and in the interstitium around blood vessels, renal tubules and glomeruli. Extensively dense collagen fibers around the glomerular capillaries were observed (Figs. 3h-i).

Immunohistochemically, the renal cortex of adult male rat kidney of the same group showed strong positive immune reaction for caspase- 3 in the cytoplasm of most tubular cells and renal glomeruli (Fig. 3j).

\section{Group IV (Cr and Se-treated group):}

However, in the group treated with $\mathrm{Cr}$ and $\mathrm{Se}$ revealed thin renal capsule surrounding the renal cortex. The renal cortex exhibited apparently normal renal glomeruli surrounded by visceral and parietal layers of Bowman's capsule with nearly normal Bowman's space. Some cortical convoluted tubules were still showing vacuolation in their cells, while other proximal and distal convoluted began to retain their normal histological architecture. Somewhat, few atrophic renal glomeruli and very small areas of interstitial hemorrhage were still observed between tubules. On the other hand no casts or inflammatory cells infiltrations were encountered (Figs. 4 a,b). 
Masson's trichrome stained sections of the same group showed moderate amounts of collagen fibers in the renal capsule, and in the renal interstitium around renal tubules, blood vessels and glomerulus. Moderately dense collagen fibers around glomerular capillaries were observed (Figs. 4c,d).

Immunohistochemically, the renal cortex of adult male rat kidney treated with $\mathrm{Cr}$ and Se showed moderately positive immune reaction for caspase3 in cytoplasm of most tubular cells and renal glomeruli (Fig. 4e).

\section{Statistical analysis:}

\section{A- Estimation of the body and kidney weight (gm):}

1- Estimation of the body weight (gm) in the different studied groups using ANOVA test revealed that there was non-significant statistical difference between Initial body weights among different groups as the $p$-value $>0.5$ while it was highly statistically significant different between final body weights of the different groups as the $p$-value $<0.001$. By using the unpaired $t$-test, there was statistical significant increase between the final and initial body weight of group III. However, by using the LSD test, the final body weight of Group III showed highly statistical significant decrease if compared with the final body weight of each group (Table 1, Chart 1).

2- Estimation of the kidney weight ( $\mathrm{gm}$ ) in the different studied group: The kidney weight (gm) in the different studied group using ANOVA test, showed a highly statistical significant difference as the $p$-value $<0.001$. However, by using the LSD test, kidney weight showed high statistical significant increase in Group III if compared with that of each group (Table. 1, Chart 2).

\section{B- The biochemical results:}

Estimation of the level of serum urea $(\mathrm{mg} / \mathrm{dl})$ in the different studied group: The mean values of level of serum urea $(\mathrm{mg} / \mathrm{dl})$ in different studied groups showed a highly statistical significant difference as the $p$-value $<0.001$. The highest mean was in group III $(40.4 \pm 3.3)$ then group IV $(16.03 \pm 3.3)$. The lowest means were in group I (15.6 \pm 1.0$)$ and group II (15.4 \pm 2.4$)$ (Table 2, Chart 3-a).

Estimation of the level of serum uric acid $(\mathrm{mg} / \mathrm{dl})$ in the different studied group: The mean values of levels of serum uric acid ( $\mathrm{mg} / \mathrm{dl})$ in the different studied group using ANOVA test showed a highly statistical significant difference as the $p$ value $<0.001$. The highest mean was in group (III) $(1.7 \pm 0.19)$. The lowest means were in group (IV)
$(0.96 \pm 0.2)$ then group (I) $(0.94 \pm 0.08)$ and group (II) $(0.93 \pm 0.07)$ (Table 2 and Chart 3-b).

Estimation of the level of serum serum creatinine $(\mathrm{mg} / \mathrm{dl})$ in the different studied group: The mean values of level of serum creatinine $(\mathrm{mg} / \mathrm{dl})$ in the different studied groups using ANOVA test showed a highly statistical significant difference as the $p$-value $<0.001$. The highest mean was in group III $(1.6 \pm 0.03)$. The lowest means were in group IV $(0.66 \pm 0.06)$ Then group I $(0.61 \pm 0.07)$ and group II $(0.6 \pm 0.07)$ (Table 2 and Chart 3-c).

\section{C- Morphometrical studies:}

The means values of diameter of glomerulus: In H\&E stained-slides per 100 high power fields, the means values of diameter of glomerulus showed highly statistical significant difference among the different studied groups as the $p$-value $<0.001$. By using the LSD test, the mean values of diameter of glomeruli of group III showed highly statistical significant decrease in comparison with group (I\& II) and was statistically significant decreased if compared with group IV (Table 3, Chart 4).

The mean values of surface areas of Bowman's space of the renal corpuscles: In H\&E stainedslides per 100 high power fields, the mean values of surface area of Bowman's space of the renal corpuscles showed a statistical significant difference among the different studied groups using ANOVA test as the $p$-value $<0.05$. By using the LSD test, there was statistical significant increase in the mean values of areas of Bowman's space in group (III) in comparison with those of each group (Table 3 , Chart 5).

The mean values of diameter of renal tubules: In H\&E stained-slides per 100 high power fields, the mean values of diameter of renal tubules showed a statistical significant difference among the different studied groups as the $p$-value $<0.05$. By using the LSD test, there was statistical significant increase in mean value of diameter of renal tubules in group (III) in comparison with those of each group (Table 3, Chart 6).

The mean values of area percentage of collagen fibers in the renal interstitium: In masson's trichrome-stained slides per 400 high power field, the mean values of area percentage of collagen fibers in the renal interstitium showed a highly statistically-significant difference among the different studied groups using ANOVA test as the $p$ value $<0.001$. By using the LSD test, there was highly statistical significant increase in area per- 
centage of collagen fibers in Group III in comparison with those of each group (Table 3, Chart 7).

The Mean values of area percentage of immune reaction for Caspase-3 in the renal interstitium: In immunohistochemical stained slides per 400 high power field, the mean area percentage of immune reaction for Caspase-3 in the renal interstitium showed a highly statistical significant difference among the different studied groups as the $p$-value $<0.001$. By using the LSD test, there was highly statistical significance increase in mean area percentage of caspase- 3 reaction in group (III) in comparison with each group (Table 3 , Chart 8).
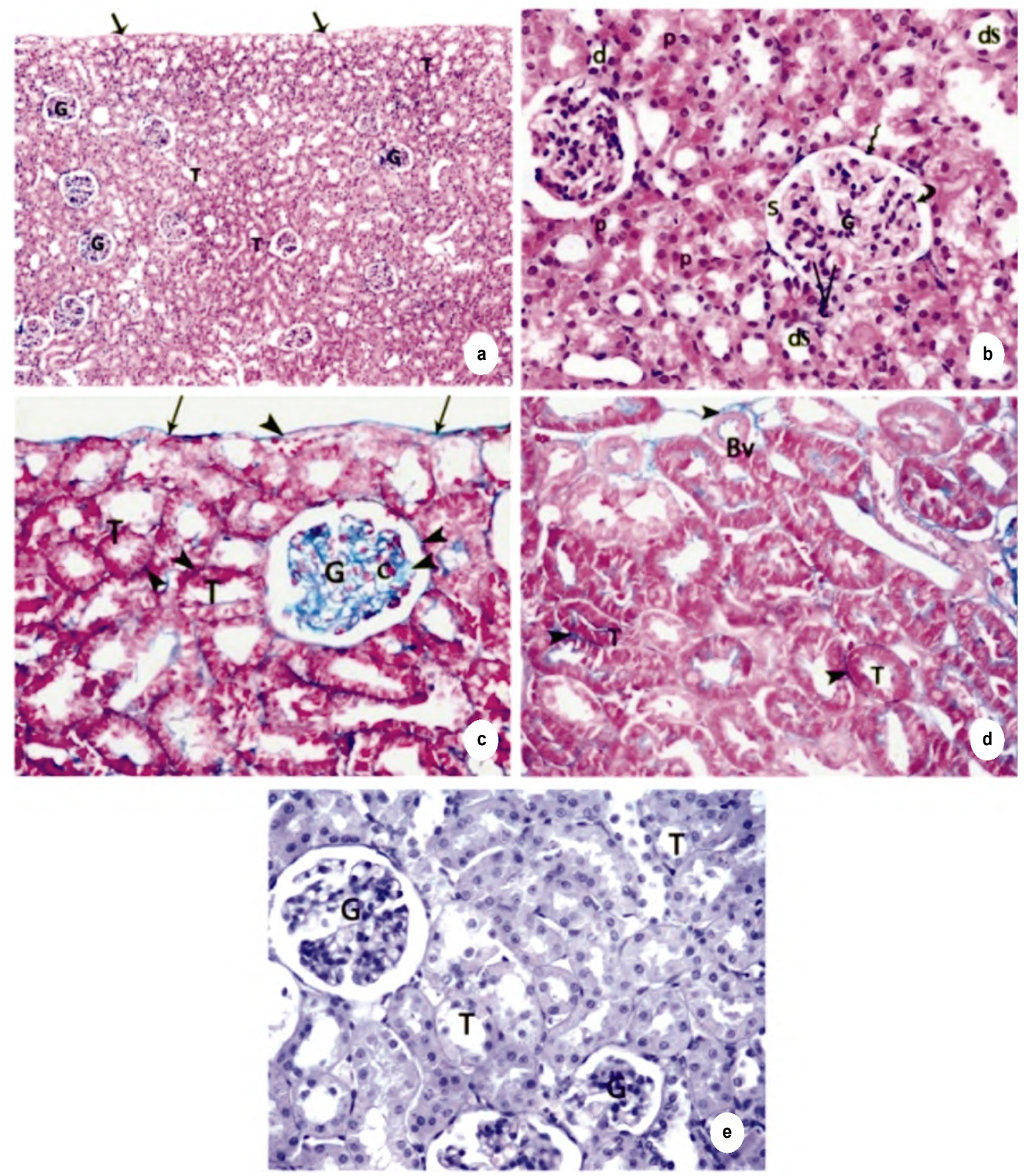

Fig. (1A-E): A photomicrograph of sections of control kidney of adult male albino rat. (a): Showing the renal cortex surrounded by thin renal capsule (arrow) and formed of renal glomeruli $(\mathrm{G})$ and cortical convoluted tubules (T). (H\&E x100) (b): Showing the glomeruli (G) formed of a tuft of glomerular capillaries (c), surrounded by visceral (curved arrow) and parietal (zigzag arrow) layers of Bowman's capsule and separated by Bowman's space (s). Proximal convoluted tubules $(\mathrm{p})$ with narrow lumen and distal (ds) convoluted tubules with wide lumen are also seen. (H\&E $\mathrm{x} 400)(\mathrm{c}-\mathrm{d})$ : Showing scanty collagen fibers (arrowheads) located in the renal capsule (arrows), around the renal glomeruli $(\mathrm{G})$, renal tubules $(\mathrm{T})$ renal blood vessel $(\mathrm{Bv})$ and less dense fibers around glomerular capillaries (c) within the glomeruli (G) are seen. (Masson's trichrome x 400) (e): Showing negative immune reaction for caspase-3 in the cytoplasm of most convoluted tubular cells (T) and renal glomeruli (G). (IHC for Caspase-3 X 400) 

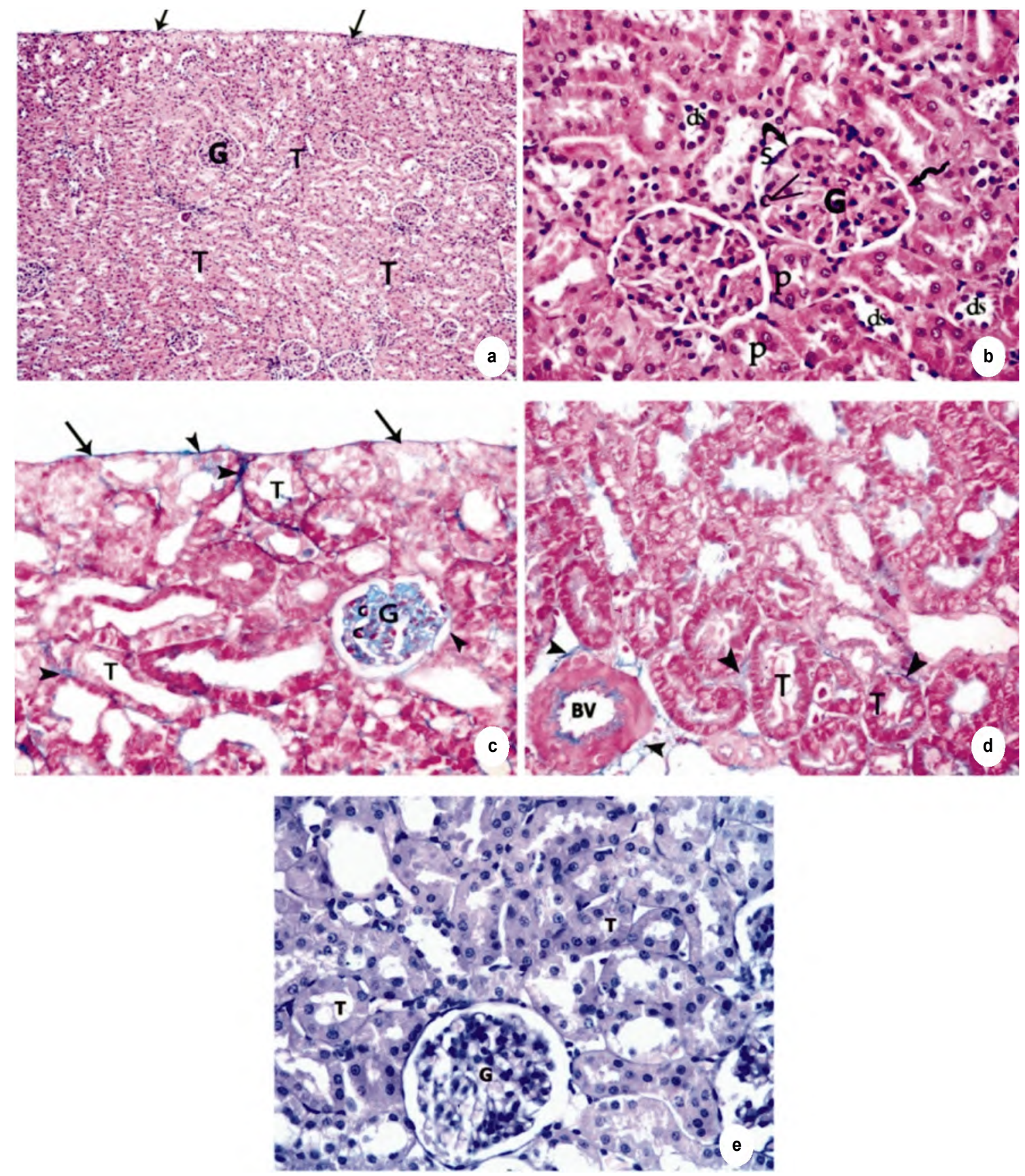

Figs. (2A-E): A photomicrograph of sections of kidney treated with selenium of adult male albino rat. (a): Showing the renal cortex surrounded by thin renal capsule (arrow) and formed of renal glomeruli (G) and cortical convoluted tubules (T). (H\&E x100) (b): Showing the glomeruli (G) formed of a tuft of glomerular capillaries (c), surrounded by visceral (curved arrow) and parietal (zigzag arrow) layers of Bowman's capsule and separated by bowman's space (s). Proximal convoluted tubules (p) with narrow lumen and distal (ds) convoluted tubules with wide lumen are also seen. (H\&E x400) (c-d): Showing scanty collagen fibers (arrowheads) located in the renal capsule (arrows), around the renal glomeruli (G), renal tubules (T) and renal blood vessel (Bv) but less dense fibers are seen around glomerular capillaries (c) within the glomeruli (G). (Masson's trichrome $\mathrm{x}$ 400) (e): Showing negative immune reaction for caspase-3 in the cytoplasm of most convoluted tubular cells (T) and renal glomeruli (G). (IHC for Caspase-3 X 400) 

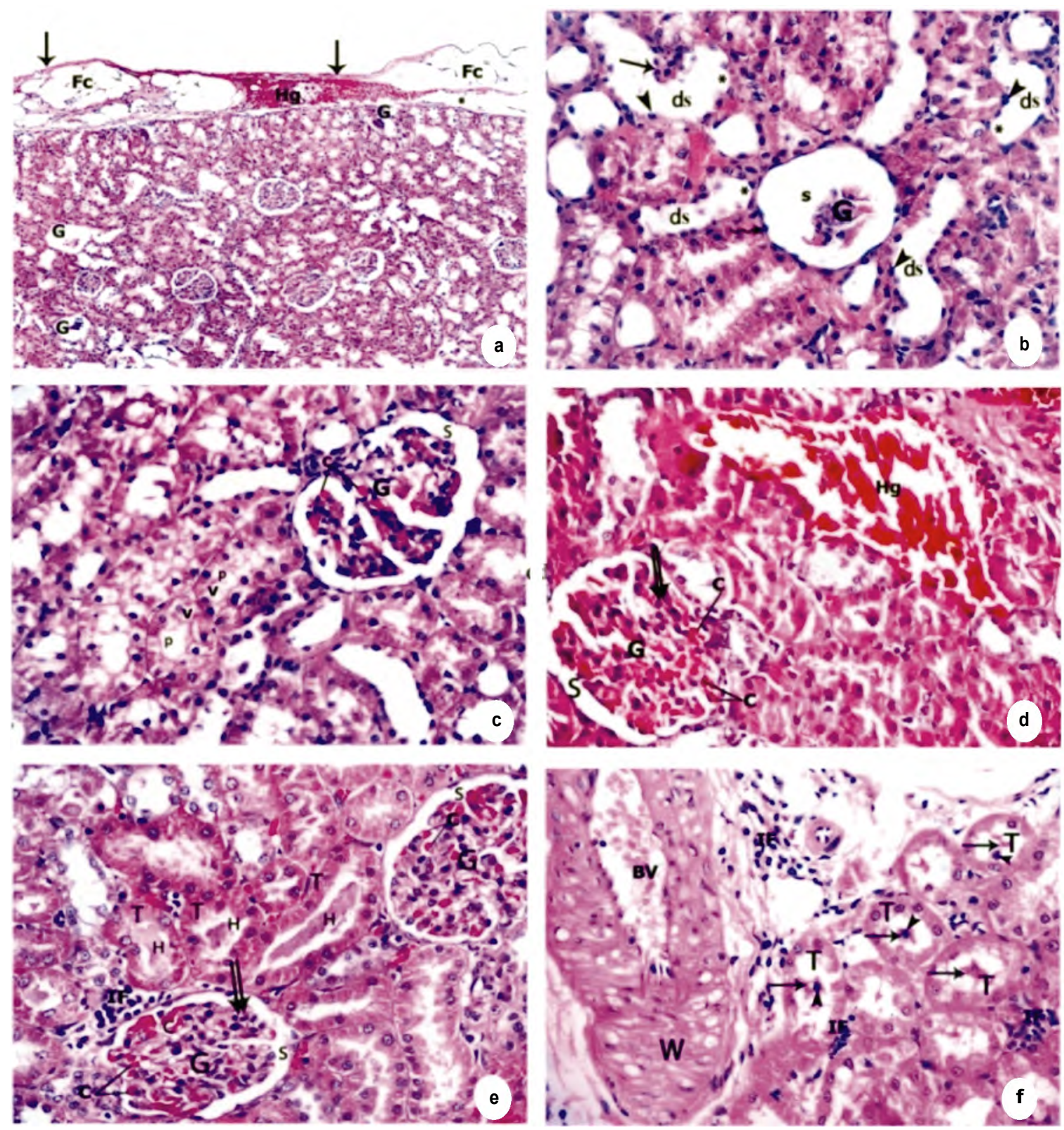

Figs. (3A-F): A photomicrograph of sections of kidney treated with Potassium dichromate of adult male albino rat. [a]: Showing thick renal capsule (arrows) with fatty cell infiltration $(\mathrm{Fc})$ and area of hemorrhage $(\mathrm{Hg})$. The capsule appears separated from the renal cortex by wide space $(*)$. Some atrophic renal glomeruli $(\mathrm{G})$ are observed in interstitial renal cortex. (H\&E x100) [b]: Showing a shrunken degenerated Glomerulus $(G)$ with dilated Bowman's space (s). The parietal layer of renal corpuscle (zigzag arrow) shows dark stained nuclei. The distal convoluted tubules (ds) appear dilated and show areas of cellular loss (*) with sloughing of their cellular lining (arrow) in their lumens. Some tubular cells appear with pyknotic nuclei (arrowhead). (H\&E x400) [c]: Showing marked lobulated glomerulus (G) with congested glomerular capillaries (c) and wide Bowman's space (s). The proximal convoluted tubules (p) display marked cytoplasmic vacuolation (V). (H\&E x400) [d-e]: Showing loss of architecture of the renal interstitium with the presence of massive area of hemorrhage $(\mathrm{Hg})$ between the tubules. Some renal cortical convoluted tubules $(\mathrm{T})$ containing homogenous acidophilic material $(\mathrm{H})$ in their lumens. Hypertrophied glomerulus $(\mathrm{G})$ is observed with congested glomerular capillaries (c), glomerular hypercellularity (double arrow) and with narrow or greatly obliterated bowman's space (s) at one side. Peri glomerular Inflammatory cell infiltrations (IF) can be noticed. (H\&E x400) [f]: Showing some cortical convoluted tubules (T) having cellular debris (arrow) containing pyknotic nuclei (arrowheads) in their lumens. Notice the congested blood vessels (BV) with markedly thick wall (W) and small focal areas of mono-nuclear inflammatory cell infiltration (IF) are seen between renal tubules $(\mathrm{T})$. (H\&E x400). 


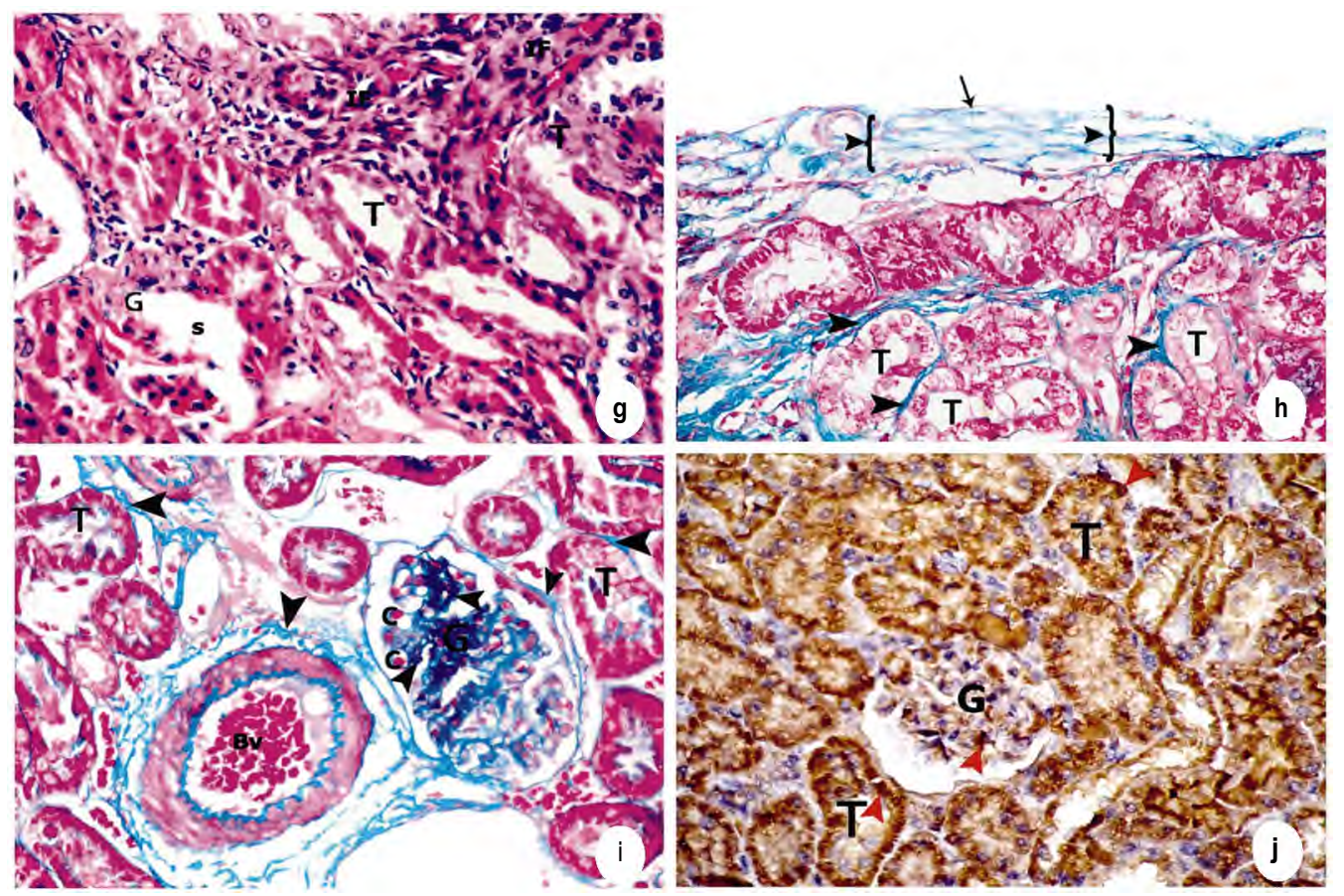

Figs. (3G-J): (g): Showing massive area of mono-nuclear inflammatory cell infiltration (IF) lying between renal tubules. Notice atrophic shrunken glomerulus $(\mathrm{G})$ with dilated bowman's space (s) is demonstrated. Notice the Cortical convoluted tubules (T) with distorted cellular lining and dilated lumens can also be seen. (H\&E $\mathrm{x} 400$ ) (h-i): Showing abundant collagen fibers (arrowheads) located in the thick renal capsule (arrow) and around renal tubules (T), around renal glomerulus (G) and blood vessels (Bv) but extensivly dense fibers around glomerular capillaries (c) within Glomeruli. (Masson's trichrome x400) (j): Showing strong positive immune reaction (red arrowheads) of caspase-3 in the cytoplasm of renal tubular cells $(\mathrm{T})$ and cytoplasm of glomeruli (G). (IHC for caspase-3 X400).
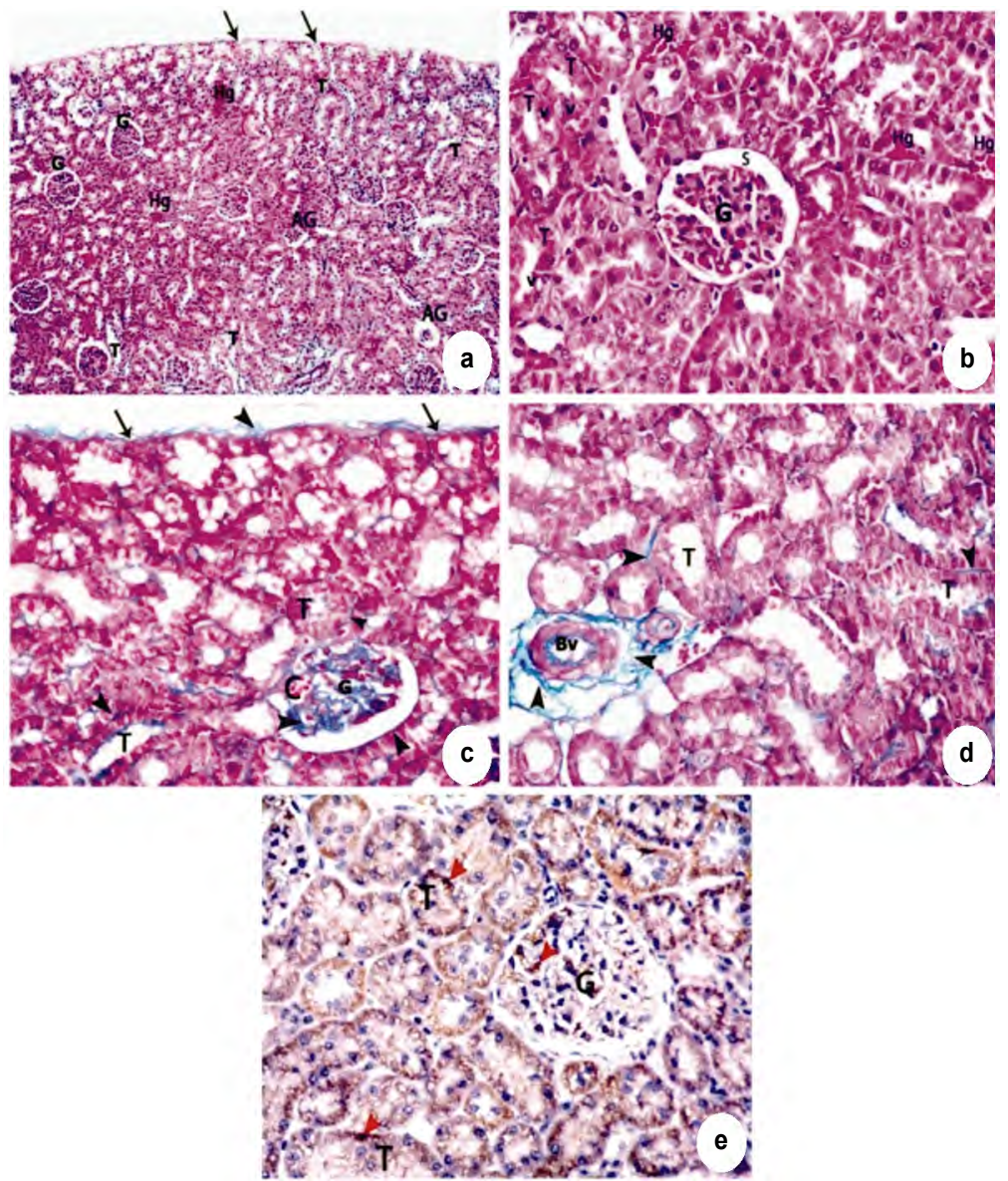

Figs. (4A-E): A photomicrograph of sections of kidney treated with Potassium dichromate and selenium of adult male albino rat. (a): Showing the renal cortex surrounded by thin renal capsule (arrow), apparently normal glomeruli (G) surrounded by convoluted tubules (T). Noticed, atrophic renal glomeruli (AG) and very small areas of interstitial hemorrhage $(\mathrm{Hg})$ are still present. (H\&E x 100) (b): Showing apparently normally renal glomeruli (G) with nearly normal Bowman's space (s). Some cortical convoluted tubules (T) with few vacuolated cells (v) and very small areas of interstitial hemorrhage $(\mathrm{Hg})$ are still observed. (H\&E x 400) (c-d): Showing moderate amounts of collagen fibers (arrowhead) located in thin renal capsule (arrow), around renal glomerulus $(\mathrm{G})$, tubules (T) renal blood vessel (Bv) but moderately dense fibers appear around renal glomerular capillaries (c) within glomeruli. (Masson's trichrome x400) (e): Showing moderately positive immune reaction (red arrowheads) of caspase- 3 in the cytoplasm of tubular cells (T) and the cytoplasm of renal glomerulus (G). (IHC for caspase-3 X400). 
Table (1): Statistical comparisons between mean values of body and kidney weights ( $\mathrm{g}$ ) in different studied groups using ANOVA (analysis of variance) test.

\begin{tabular}{|c|c|c|c|c|c|c|}
\hline Parameter & $\begin{array}{c}\text { Group I } \\
\text { Mean } \pm \text { SD }\end{array}$ & $\begin{array}{c}\text { Group II } \\
\text { Mean } \pm \text { SD }\end{array}$ & $\begin{array}{l}\text { Group III } \\
\text { Mean } \pm \text { SD }\end{array}$ & $\begin{array}{c}\text { Group IV } \\
\text { Mean } \pm \text { SD }\end{array}$ & $\mathrm{F}$ & $p$ \\
\hline Initial body weight (g) & $170.5 \mathrm{a} \pm 12.3$ & $171.1 \mathbf{a} \pm 9.1$ & $173.5^{\mathrm{a} \pm 9.1}$ & $173.5^{\mathrm{a}} \pm 14.1$ & 0.19 & $0.89 \mathrm{Ns}$ \\
\hline Final body weight (g) & $229.1^{\mathbf{a}} \pm 16.9$ & $264.3^{\mathbf{b}} \pm 16.04$ & $186.3^{\mathbf{c}} \pm 10.7$ & $220.7 \mathbf{a} \pm 16.8$ & 39.23 & $<0.001^{* *}$ \\
\hline$p \#$ & $<0.001 * *$ & $<0.001 * *$ & $* 0.014$ & $<0.001 * *$ & & \\
\hline Kidney weight & $0.794 \mathrm{a} \pm 0.09$ & $0.789 \mathbf{a}_{ \pm 0.1}$ & $1.187 \mathbf{b} \pm 0.3$ & $0.793 \mathrm{a} \pm 0.13$ & 10.87 & $<0.001 * *$ \\
\hline
\end{tabular}

\#: Paired $t$-test comparing initial and final BW of each group.

Groups with the same letters are statistically insignificant $(p>0.05)$.

Group I (control group).

**: Highly significant. *: Significant. NS: Non-significant.

Group II (Se-treated group).

Group III (Cr-treated group).

Group IV (Cr and Se-treated group).

Table (2): Statistical comparisons between mean values of serum urea, creatinine and uric acid (mg/dl) in different studied groups using ANOVA (analysis of variance) test.

\begin{tabular}{lcccccc}
\hline Parameter & $\begin{array}{c}\text { Group I } \\
\text { Mean } \pm \text { SD }\end{array}$ & $\begin{array}{c}\text { Group II } \\
\text { Mean } \pm \text { SD }\end{array}$ & $\begin{array}{c}\text { Group III } \\
\text { Mean } \pm \text { SD }\end{array}$ & $\begin{array}{c}\text { Group IV } \\
\text { Mean } \pm \text { SD }\end{array}$ & F & $p$ \\
\hline Serum Urea & $15.6 \pm 3.1^{\mathbf{a}}$ & $15.4 \pm 2.4^{\mathbf{a}}$ & $40.4 \pm 3.6^{\mathbf{b}}$ & $16.03 \pm 3.3^{\mathbf{a}}$ & 138.6 & $<0.001^{* *}$ \\
Serum Uric Acid Level & $0.94 \pm 0.08^{\mathbf{a}}$ & $0.93 \pm 0.07^{\mathbf{a}}$ & $1.7 \pm 0.19^{\mathbf{b}}$ & $0.96 \pm 0.2^{\mathbf{a}}$ & 58.84 & $<0.001^{* *}$ \\
Serum creatinine level & $0.61 \pm 0.07^{\mathbf{a}}$ & $0.6 \pm 0.07^{\mathbf{a}}$ & $1.6 \pm 0.03^{\mathbf{b}}$ & $0.66 \pm 0.06^{\mathbf{a}}$ & 5386 & $<0.001^{* *}$ \\
\hline
\end{tabular}

F : Anova test.

** : Highly significant $(p<0.01)$.

LSD: Groups with same letters are statistically insignificant $(p>0.05)$.

Group I (control group).

Group II (Se-treated group).

Group III (Cr-treated group).

Group IV (Cr and Se-treated group).

Table (3): Statistical comparisons between mean values of different morphometrical parameters in different studied groups using ANOVA (analysis of variance) test.

\begin{tabular}{|c|c|c|c|c|c|c|}
\hline Parameter & $\begin{array}{c}\text { Group I } \\
\text { Mean } \pm \text { SD }\end{array}$ & $\begin{array}{c}\text { Group II } \\
\text { Mean } \pm \text { SD }\end{array}$ & $\begin{array}{l}\text { Group III } \\
\text { Mean } \pm \text { SD }\end{array}$ & $\begin{array}{l}\text { Group IV } \\
\text { Mean } \pm \text { SD }\end{array}$ & $\mathrm{F}$ & $p$ \\
\hline Diameter of glomerulus ( $\mathrm{m})$ & $87.39 \pm 7.4$ & $87.38 \mathbf{a} \pm 19.9$ & $63.2^{\mathbf{a} \pm 5.1}$ & $78.6^{\mathbf{a} \pm 10.6}$ & 7.934 & $0.000 * *$ \\
\hline Surface area of bowman's space $\left(\mathrm{m}^{2}\right)$ & $2309.4^{a} \pm 270.7$ & $2309.04^{a} \pm 679.7$ & $3308.3^{\mathbf{b}_{ \pm}}$ & $2524^{\mathrm{a}} \pm 758.5$ & 5.06 & $0.006^{*}$ \\
\hline Diameter of renal tubules $(\mathrm{m})$ & $90.3^{\mathbf{a}} \pm 17.8$ & $90.04 \mathbf{a} \pm 19.2$ & $112.2^{\mathbf{b}} \pm 18.5$ & $91.6^{\mathbf{a} \pm 13.5}$ & 3.52 & $0.026^{*}$ \\
\hline Area percentage of collagen fibers & $1.91 \mathrm{a} \pm 0.6$ & $1.9 \mathrm{a} \pm 0.76$ & $21.9^{\mathbf{b}} \pm 4.9$ & $4.3^{c_{ \pm}} \pm .9$ & 131.4 & $0.000 * *$ \\
\hline
\end{tabular}

Group I (control group).

Group II (Se-treated group).

Group III (Cr-treated group)

Group IV (Cr and Se-treated group)
Groups with the same letters are statistically insignificant $(p>0.05)$.

** : Highly significant.

* : Significant

NS: Non-significant.

Chart (1): Bar chart showing comparison between mean values of body weight (gm) among the different studied groups.
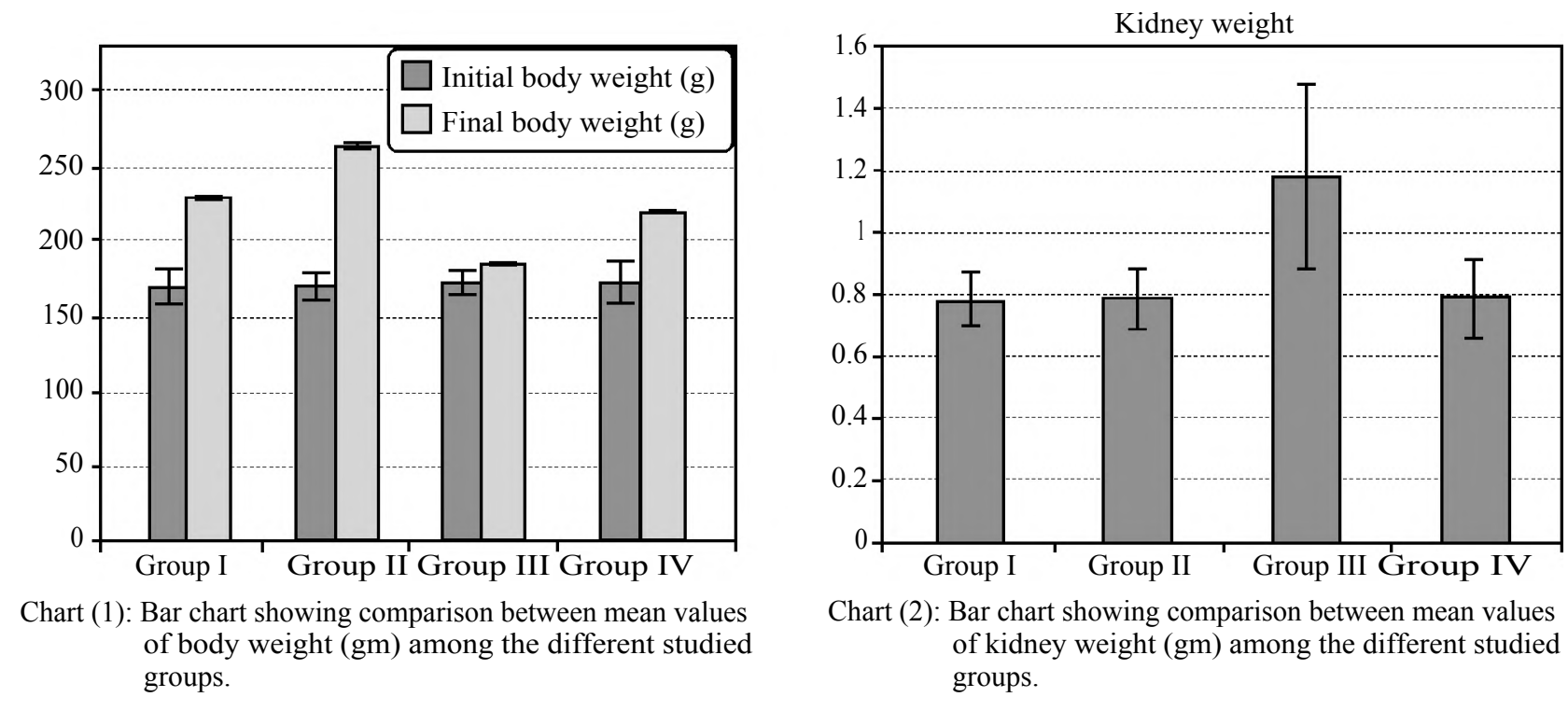

Chart (2): Bar chart showing comparison between mean values of kidney weight (gm) among the different studied groups. 

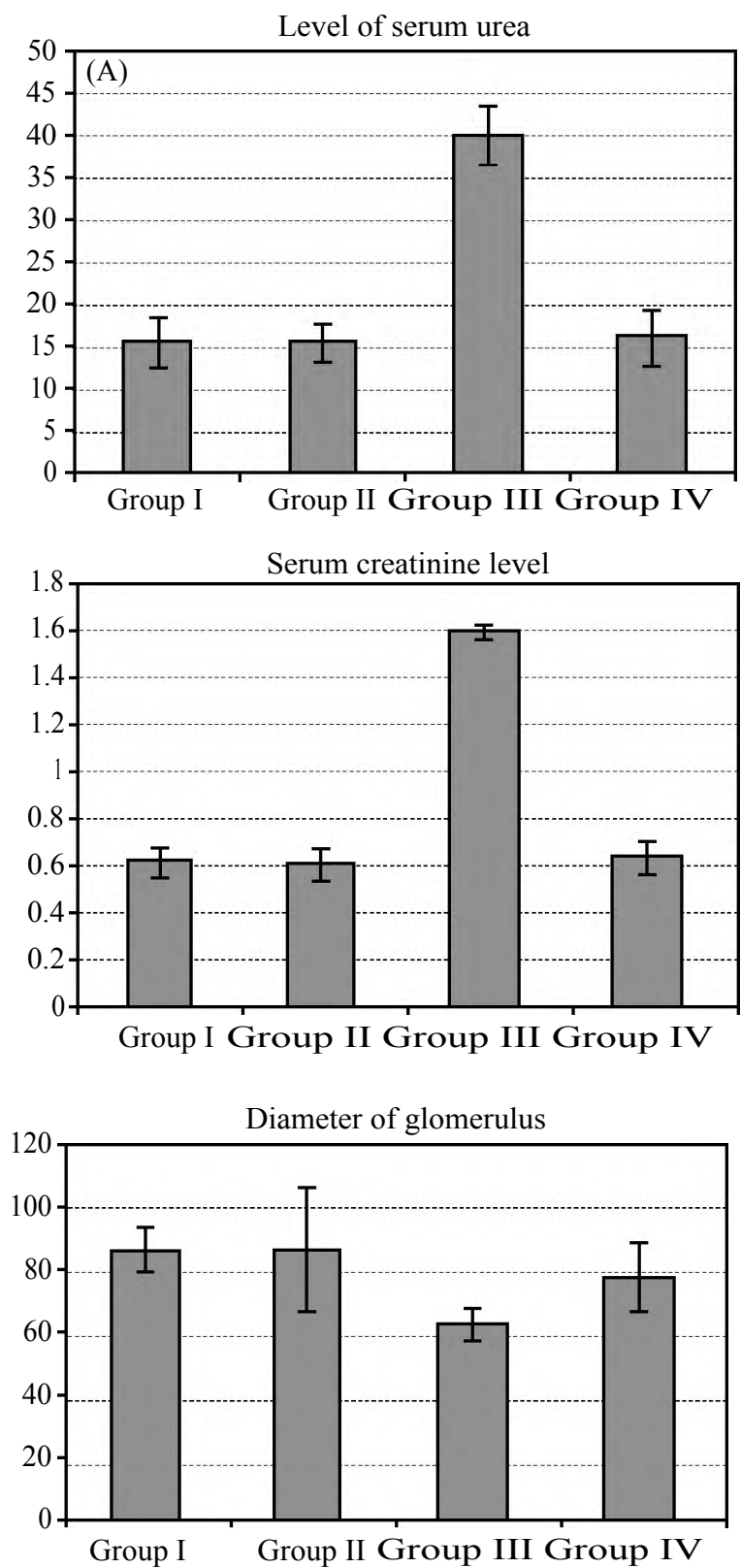

Chart (4): Bar chart showing comparison between mean values of diameter of glomeruli $(\mu \mathrm{m})$ among the studied groups.

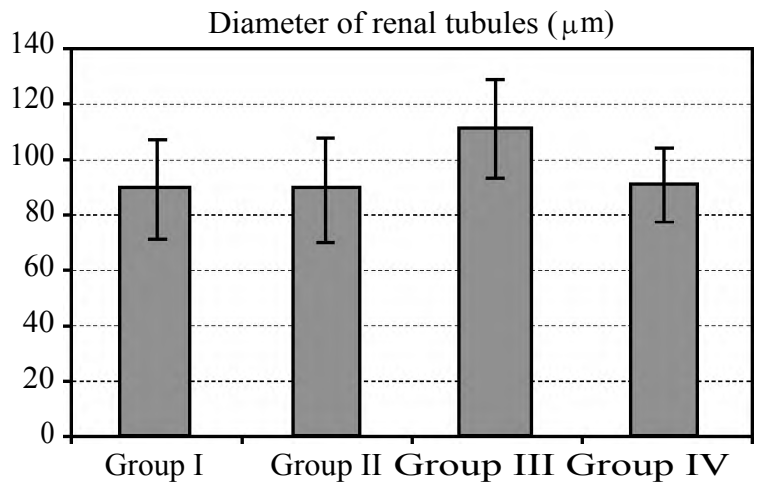

Chart (6): Bar chart showing comparison between mean values of diameter of renal tubules $(\mu \mathrm{m})$ among the studied groups.

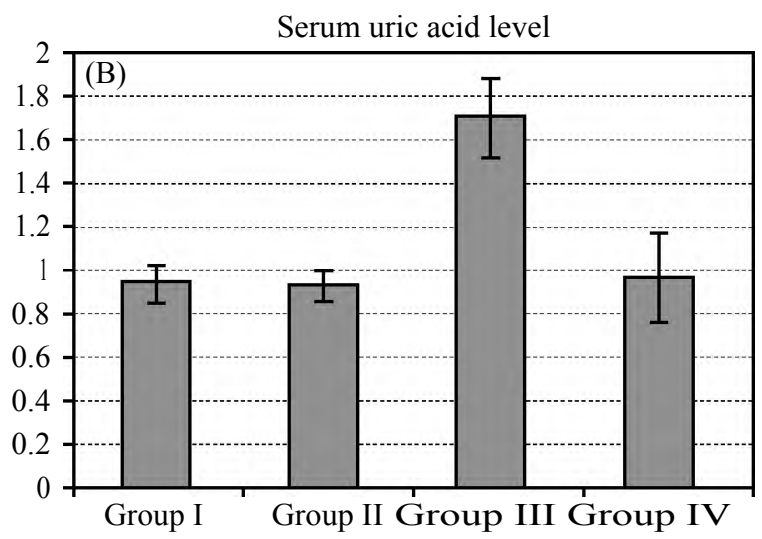

Chart (3A,B,C): Bar charts showing comparison between mean values of serum urea, serum uric acid and serum creatinine among the different studied groups.

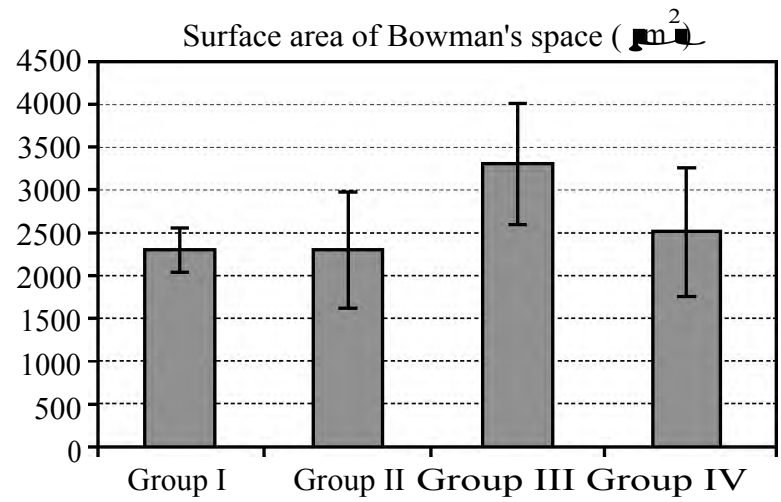

Chart (5): Bar chart showing comparison between mean values of surface area of Bowman's space $\left(\mathrm{tm}^{2}\right)$ among the studied groups.

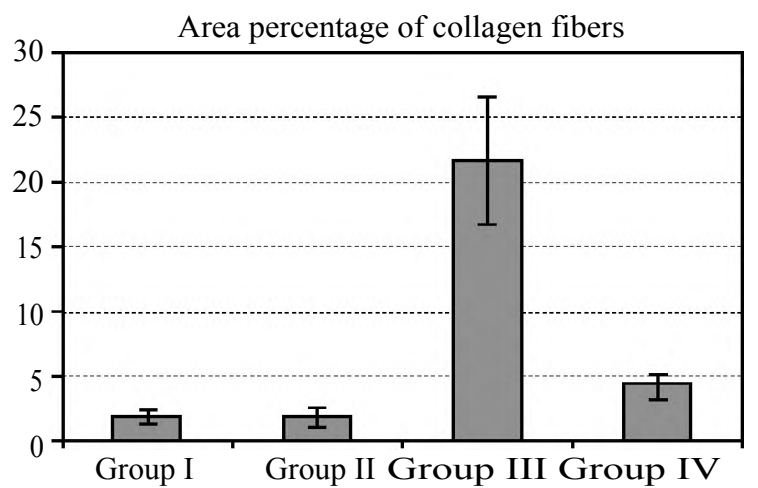

Chart (7): Bar chart showing comparison between mean values of area percentage of collagen fibers among the studied groups. 


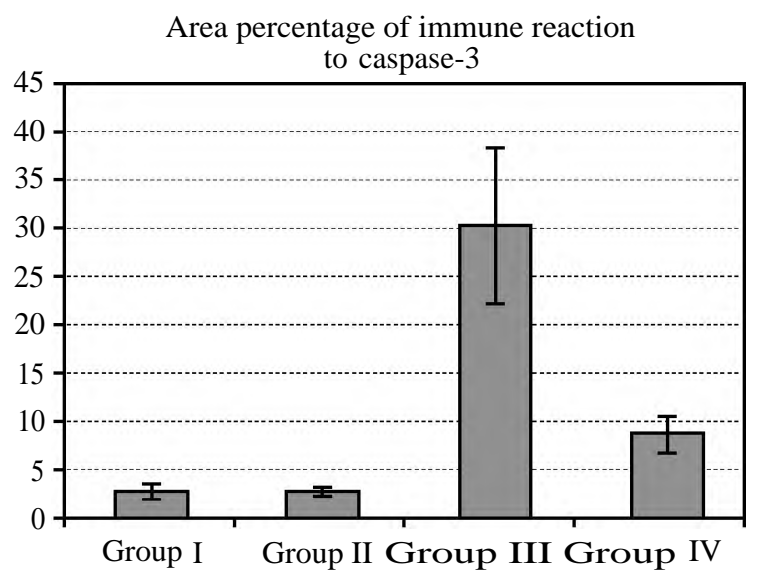

Chart (8): Bar chart showing comparison between mean values of area percentage of immune reaction to caspase3 among the studied.

\section{Discussion}

Cr has been shown to induce nephrotoxicity associated with oxidative stress in humans and animals. They are rapidly absorbed and more corrosive than other valence states [15]. In the present work, the results showed that the mean values of final body weights of albino rats in group III showed a statistical significant increase if compared with its initial body weights, however, the final body weights of albino rats in the same group showed a high significant decrease if compared with the final body weight of each group. This observation indicated weak body weight gain in this CR-treated group. On the other hand, Kidney weight showed a highly statistical this work were in agreement with Elshazly et al., and Bashandy et al., $[16,17]$ who found out that after intoxication of rats with potassium dichromate induced significant decrease in body weight gain but showed a significant increase in kidney weight in comparison with normal control group. They attributed the increase in kidney weight to pathological changes that took place in renal parenchyma in the form of congestion and nephritis. On the contrary, Soudani et al., [18] detected no significant changes in body and kidney weight between potassium dichromate treated rats and other groups.

$\mathrm{Cr}$ induced different histopathological changes in the renal cortex. Haematoxylin and eosin-stained sections in group III revealed massive destructive damage of renal cortex. Fatty cell infiltration and area of hemorrhage were seen within thick renal capsule. De-Vries et al., [19] stated that in vivo and in vitro experiments, there was an association between intrarenal accumulation of lipid components and renal injury. In addition, Shanmugam et al., [20] reported fatty infiltration in renal tissue of diabetic rat and attributed this to oxidative stress that led to free radicals formation and abnormal fat metabolism.

Concerning the renal glomeruli in this work, there was variable forms of pathological damage of them including; shrinkage, atrophy, marked lobulation and hypertrophy of renal glomeruli, glomerular hypercellularity, congestion of glomerular capillaries, widening or obliteration of bowman's space and dark staining of nuclei of parietal cell layer. The shrinkage and atrophy of renal glomeruli that were observed in this work were in consistence with Soudani et al., [18] who demonstrated shrunken glomerulus with widening of bowman's space when they gave the same dose orally. Also, Hegazy et al., [21] detected the same results in their study in addition to thickening of glomerular basement membrane. Mayer [22] explained the relationship between tubule-interstitial nephritis and glomerular injury as tubular injury associated with tubular obliteration affect the flow of glomerular filtrate. If the glomerular filtration rate was slowed or stopped, glomerular shrinkage and sclerosis occurred. Moreover, Apostolova et al., [23] and L'Azou et al., [24] attributed the glomerular shrinkage to the disruption of the cytoskeleton of the mesangial cells and their contraction.

Regarding the vacuolar formation of proximal convoluted tubules of the present study, similar findings was proved before by, Hegazy et al., [21] who revealed severe necrobiotic changes in almost proximal convoluted tubules and explained that the tubular damage and nephrotoxic effect of chromate resulted from its accumulation in vacuoles inside the proximal tubular cells that lead to slow excretion and remaining of $\mathrm{Cr}$ in the kidney for a long time.

Deposition of acidophilic hyaline material was also observed in this work. Hegazy et al., [21] reported that the treated animals revealed intraluminal and intracytoplamic accumulation of hyaline droplet and renal cast.

Assessment of the kidney functions had been made in the present work by estimating the BUN, $\mathrm{Bc}$ and UA. There was highly statistical significance increase in BUN, Bc and UA level in Cr-treated group in comparison to other groups. However; there was no statistical difference between control groups and ( $\mathrm{Cr}$ and Se-treated group). Serum creatinine, urea and uric acid level decreased in $(\mathrm{Cr}$ and Se-treated group) denoting importance of $\mathrm{Se}$ in restoration of kidney function induced by $\mathrm{Cr}$ - 
intoxication. Mehany et al., [4] showed marked increase in $\mathrm{Bc}$ and $\mathrm{BUN}$ levels following single subcutaneous injection of potassium dichromate. The increase in these parameters was due to loss of functional integrity in the kidney and distortion of renal tubules as result of $\mathrm{Cr}$ administration. They also revealed anti-oxidant effect of vit $\mathrm{E}$ and atorvastatin in restoration of BUN and Bc level.

Sahu et al., [25] also supported significant increase in level of BUN and Bc in CR-treated group given the previous dose when compared with control group. They mentioned that pretreatment with carvedilol significally lowered BUN and Bc plasma levels. They added that increased level of BUN and $\mathrm{Bc}$ resulted from injures of tubules by $\mathrm{CR}$ and their obstruction by cell debris.

In this study, there were highly statistical significance decrease in the mean values of diameter of glomeruli, between group III and groups (I\&II). Regarding the mean values of surface areas of Bowman's space of the renal corpuscles, there was statistical significance increase in area of Bowman's space in group (III) if compared with other groups. Both results were in close to the observation of Elshazly et al., [16]. They showed significant increase in bowman's space and decrease in glomerular diameter in comparison to control group and (chromium and spirulina treated group). They attributed these changes to wide spread shrinkage of glomeruli and widening of bowman's space as result of potassium dichromate exposure.

Concerning the hypertrophy of renal glomeruli, hypercellularity and congestion of glomerular capillaries that were observed in this study, were in concomitant with Stoev et al., and Saber et al., $[26,27]$. They postulated the increase in glomerular size may due to glomerular endothelial proliferation.

As regard to the renal tubules in this work, there were tubular dilatation, tubular cell necrosis, sloughing of necrotic tubular epithelial cells into the lumens of distal convoluted tubules and marked cytoplasmic vacuolization of proximal tubular cells. Moreover, the morphometeric and statistical analysis of this study indicated statistical significant increase in mean value of diameter of renal tubules in group (III) in comparison with those of each group. These results were in consistence with those obtained by Saber et al., [27] when they examined kidney section of rats treated with potassium dichromate 3times/week for 4 weeks and recorded tubular dilatation with vacuolation and necrosis. On contrary, Elshazly et al., [16] mentioned significant decrease in proximal and distal convoluted tubules lumen areas as a result of cellular swelling.
The presence of massive interstitial hemorrhage together with congestion of blood vessels and thickening in their walls in this work was in accordance with Brzoska et al., [28] that attributed the hemorrhage to the thickening of the capillary vessels and widening of the endothelial spaces. Lenz et al., [29] clarified that mesangial cells synthesize the structural components of extracellular matrix (ECM), mainly collagen fibers and matrix metalloproteinases (MMP). Histological examination using Masson's trichrome staining of the current study showed abundant collagen fibers in the thick renal capsule, around blood vessels, renal tubules, glomeruli with extensively dense fibers around glomerular capillaries in group III. However; these fibers were scanty in groups (I\&II) and moderately in group IV. Moreover by morphometeric and statistical analysis, there was highly statistical significance increase in area percentage of collagen fibers between Group III and each group. These results were in concomitant with what reported by EL-Mahalawy et al., [30] . They reported that there was significant increase in collagen fibers around degenerated convoluted tubules.

The expression of caspase- 3 was in the cytoplasm of most tubular cells and renal glomeruli and showed strong positive immune reaction in group III however was negative in groups (I\&II) and was moderately positive in group IV. Moreover by statistical analysis, there was highly statistical significance increase in area percentage of caspase3 expression between Group III and each group. These results were in accordance with Nagma et al., [31] who reported that potassium dichromate induced renal tubular cells apoptosis. Apoptosis is usually required for controlling cell numbers by eradicating injured or impaired cells for better functioning of the body. But an uncontrolled and unconditioned apoptosis causes tissue damage.

On the other hand, Hassanin et al., [32] reported that selenium had antioxidant and anti-apoptotic effects protecting against oxidative stress and fibrosis caused by hexavalent chromium.

In present study, the treatment with selenium in group IV produced mild improvement in the renal cortex. The renal glomeruli, proximal and distal convoluted tubules began to retain their normal histological architecture and biochemical parameters. These results were in agreement with Soudani et al., [18] who reported that administration of Se through diet of potassium dichromate treated group improved histological alteration. This could be attributed to antioxidant, antiradical and metal 
chelating efficacy of Se [33]. Ognjanovic et al., [34] added that the major role of sodium selenite was in inhibiting lipid peroxidation and in protecting the wholeness and functioning of tissues and cells.

Conclusion: Administration of Se simultaneously with $\mathrm{Cr}$ improved the deleterious histological and biochemical changes induced by $\mathrm{Cr}$ exposure.

Recommendations: Limiting the occupational and environmental exposure to $\mathrm{Cr}$ is necessary. Special precautions must be taken to limit the level of water contamination with Cr. Selenium supplementation is important to limit the toxic effects of $\mathrm{Cr}$ on the renal cortex especially in highly exposed individuals.

\section{Compliance with ethical standards:}

Conflict of interest The author declares that he has no conflict of interest. he author declares that he has no conflict of interest.

\section{References}

1- LEONARD S.S., HARRIS G.K. and SHI X.: Metalinduced oxidative stress and signal transduction. Free Radical Biology and Medicine, 37 (12): 1921-1942. https://doi.org/10.1016/j.freeradbiomed.2004.09.010, 2004.

2- ARREOLA-MENDOZA L., REYES J.L., MELENDEZ E., MARTÍN D., NAMORADO M.C., SANCHEZ E. and DEL RAZO L.M.: Alpha-tocopherol protects against the renal damage caused by potassium dichromate. Toxicology, 218 (2): 237-246. https://doi.org/10.1016/j.tox.2005 11.010, 2006

3- WU F., SUN H., KLUZ T., CLANCY H.A., KIOK K. and COSTA M.: Epigallocatechin-3-gallate (EGCG) protects against chromate-induced toxicity in vitro. Toxicology and applied pharmacology. 258 (2): 166-175. https:// doi.org/10.1016/j.taap.2011.10.018, 2012.

4- MEHANY H.A., ABO-YOUSSEF A.M., AHMED L.A., ARAFA E.S.A. and EL-LATIF H. A.A.: Protective effect of vitamin $\mathrm{E}$ and atorvastatin against potassium dichromate-induced nephrotoxicity in rats. Beni-Suef University Journal of Basic and Applied Sciences, 2 (2): 96-102. https://doi.org/10.1016/j.bjbas.2013.02.002, 2013.

5- GOODARZI Z., KARAMI E. and AHMADIZADEH M.: Simvastatin attenuates chromium-induced nephrotoxicity in rats. Journal of Nephropathology, 6 (1): 5-9. doi: 10. 15171/jnp.2017.02, 2017.

6- SADEK K.M.: Chemotherapeutic efficacy of an ethanolic Moringa oleifera leaf extract against chromium-induced testicular toxicity in rats. Andrologia. 46 (9): 1047-1054. DOI:10.1111/and.12196, 2014.

7- C` OBANOVÁ K., FAIX Ś .; PLACHÁ I.; MIHALIKOVÁ K., VÁRADYOVÁ Z. KIS IDAYOVÁ S. and GRESÁKOVÁ L'.: Effects of Different Dietary Selenium Sources on Antioxidant Status and Blood Phagocytic Activity in Sheep. Biological. Trace. Element. Research., 175 (2): 339-346. Doi: 10. 1007/s1201 1-016-0794-0, 2017.
8- ASLANTURK A., UZUNHISARCIKLI M., KALENDER S. and DEMIR F.: Sodium selenite and vitamin E in preventing mercuric chloride induced renal toxicity in rats. Food and Chemical Toxicology, 70: 185-190. https://doi. org/10.1016/j.fct.2014.05.010.

9- SOUDANI N., SEFI M., AMARA I.B., BOUDAWARA T. and ZEGHAL N.: Protective effects of selenium (Se) on chromium (VI) induced nephrotoxicity in adult rats. Ecotoxicology and Environmental Safety, 73 (4): 671 678. https://doi.org/10.1016/j.ecoenv.2009.10.002, 2010.

10- DEY S.K., DOLAI D.P., DASH S.K., MANDAL D., DAS B. and ROY S.: Sodium Selenite Attenuates ChromiumInduced Membrane Damage. Eur. J. Health. Sci., 2 (3): 89-97. doi: 10.5505/eurjhs.2016.43433, 2016.

11- Bancroft J.D. and Layton C.: The hematoxylin and eosin, connective and mesenchymal tissues with their stains. In: Suvarna S.K., Layton C., Bancroft J.D. editors. Bancroft's theory and practice of histological techniques. $7 \mathrm{t}^{\mathrm{h}}$ ed. Philadelphia: Churchill Livingstone, pp. 173-212. 2013.

12- KRAJEWSKA M., WANG H.G., KRAJEWSKI S., SHABAIK A., GASCOYNE R. and REED J.C.: Immunohistochemical analysis of in vivo pattern of expression of CPP32 (Caspase 3), a cell death protease. Cancer. Res., 57: 1605-1631. 1997.

13- JACKSON P. and BLYTHE D.: Immunohistochemical techniques. In: Suvarna S.K., Layton C., Bancroft J.D. editors. Theory \& practice of histological techniques $\mathrm{Ch}$. 18. $7 \mathrm{t}^{\mathrm{h}}$ ed. Philadelphia: Churchill Livingstone of $\mathrm{El}$ Sevier, pp. 386-431. 2013.

14- DEAN A.G., DEAN J.A. and COULOMBIER D.: A word processing data base and statistical program for epidemiology and microcomputer office, Center for disease control, Atlanta Georgia, USA. Epi-Info.m (6.1). 2000.

15- PELLERIN C. and BOOKER S.M.: Reflections on hexavalent chromium: Health hazards of an industrial heavyweight. Environmental Health Perspectives. 108: (9). 2000. doi: 10.1289/ehp.108-a402.

16- ELSHAZLY M.O., EL-RAHMAN S.S.A., MORGAN A.M. and ALI M.E.: The remedial efficacy of Spirulina platensis versus chromium-induced nephrotoxicity in male sprague-dawley rats. PloS one., 10 (6). doi: 10.1371/journal.pone.0126780, 2015.

17- BASHANDY S.A., AMIN M.M., MORSY F.A. and ELMARASY S. A.: Amelioration of the nephrotoxic effect of potassium dichromate by whey protein and/or Nigella sativa oil in male albino rats. Journal of Applied Pharmaceutical Science Vol., 6 (08), pp. 044-050. DOI: 10.7324 /JAPS.2016.60807, 2016.

18- SOUDANI N., SEFI M., AMARA I.B., BOUDAWARA T. and ZEGHAL N.: Protective effects of selenium (Se) on chromium (VI) induced nephrotoxicity in adult rats. Ecotoxicology and Environmental Safety, 73 (4): 671678. https://doi.org/10.1016/i.ecoenv.2009.10.002, 2010.

19- De VRIES A.P., RUGGENENTI P., RUAN X.Z., PRAGA M., CRUZADO J.M., BAJEMA I.M. and ABBATE M.: Fatty kidney: Emerging role of ectopic lipid in obesityrelated renal disease. The Lancet Diabetes \& Endocrinology. 2 (5): 417-426. https://doi.org/10.1016/S2213-8587 (14) 70065-8, 2014.

20- SHANMUGAM K.R., RAMAKRISHNA C.H., MALLIKARJUNA K. and REDDY K.S.: Perturbation in kidney 
lipid metabolic profiles in diabetic rats with reference to alcoholic oxidative stress. Indian Journal of Nephrology, 19 (3): 101-106. doi: 10.4103/0971-4065.57106, 2009.

21- HEGAZY R., SALAMA A., MANSOUR D. and HASSAN A.: Renoprotective Effect of Lactoferrin against Chromium-Induced Acute Kidney Injury in Rats: Involvement of IL-18 and IGF-1 Inhibition. PloS One., 11 (3): 1-18. DOI:10.1371/ journal.pone.0151486, 2009, 2016.

22- MAYER T.: Tubular injury in renal disease. Kidney Intrnational, 63: 774-787. DOI:10.1046/j. 1523-1755.2003. 00795, 2003.

23- APOSTOLOVA M.D., CHRISTOVA T. and TEMPLETON D.M.: Involvement of gelsolin in cadmium-induced disruption of the mesangial cell cytoskeleton. Toxicological Sciences, 89 (2): 465-474. https://doi.org/10.1093/toxsci/ kfj035, 2005.

24- L'AZOU B., DUBUS I., OHAYON-COURTÈS C. and CAMBAR J.: Human glomerular mesangial IP15 cell line as a suitable model for in vitro cadmium cytotoxicity studies. Cell Biology and Toxicology, 23 (4): 267-278, doi: 10.1007/s10565-006-0888-0, 2007.

25- SAHU B.D., KONERU M., BIJARGI S.R., KOTA A. and SISTLA R.: Chromium-induced nephrotoxicityt and ameliorative effect of carvedilol in rats: Involvement of oxidative stress, apoptosis and inflammation. Chemicobiological Interaction, 223 : 69-79. https://doi.org/10.1016/ j.cbi.2014. 09.009, 2014.

26- STOEV S.D., GROZEVA N., SIMEONOV R., BORISOV I., HUBENOV H., NIKOLOV Y. and LAZAROVA S.: Experimental cadmium poisoning in sheep. Experimental and Toxicologic Pathology, 55 (4): 309-3 14. https://doi.org/ 10.1 078/0940-2993-003 33, 2003.

27- SABER T.M., FARAG M.R. and COOPER R.G.: Ameliorative effect of extra virgin olive oil on hexavalent chromium-induced nephrotoxicity and genotoxicity in rats. Rev. Méd. Vét., 166: 11-19. 2015.
28- BRZOSKA M.M., MONIUSZKO-JAKONIUK J., PIL AT-MARCINKIEWICZ B. and SAWICKI B.: Liver and kidney function and histology in rats exposed to cadmium and ethanol. Alcohol and Alcoholism, 38 (1): 2-10. https://. doi.org/10.1093/alcalc/agg006, 2003.

29- LENZ O., ELLIOT S. and STETLER W.: Matrix metalloproteinases in renal development and diseases. Journal of American Society of Nephrology, 11 (3) 574-581. 2000.

30- EL-MAHALAWAY A.M., SALEM M.M. and MOUSA A.M.: The effect of potassium dichromate on convoluted tubules of the kidney of adult male albino rats and the possible protective role of ginseng: A histological and immunohistochemical study. Egyptian Journal of Histology. 38 (2): 157-167. DOI: 10.1097/01.EHX. 0000464738. 41270.06, 2015.

31- NAGMA G., ASHRAF J., SIDDIQUE J. NAGMA M. and ABDUR R.: Curcumin attenuates chromium induced hepato and renal toxicity in mice. Int Pharm Sci., 2: 1723. 2012.

32- HASSANIN K.M., EL-KAWI S.H.A. and HASHEM K.S.: The prospective protective effect of selenium nanoparticles against chromium-induced oxidative and cellular damage in rat thyroid. International Journal of Nanomedicine, 8: 1713-1720. 2013. doi: 10.2147/IJN.S42736, 2015.

33- AL-OTHMAN, A. M.; AL-NUMAIR, K. S.; EL-DESOKY, G.E., YUSUF K., AL OTHMAN Z.A., ABOUL-SOUD, M.A. and GIESY J.P.: Protection of-tocopherol and selenium against acute effects of malathion on liver and kidney of rats. African Journal of Pharmacy and Pharmacology, 5 (10): 1263-1271. https://doi.org/10.5897/ AJPP11.226, 2011.

34- OGNJANOVIC B.I., MARKOVIC S.D., PAVLOVIC S. Z., ZIKIC R.V., STAJN A.S. and SAICIC Z.S.: Effect of chronic cadmium exposure on antioxidant defense system in some tissues of rats: Protective effect of selenium. Physiological. Research, 57 (3): 403-411. 2008. 


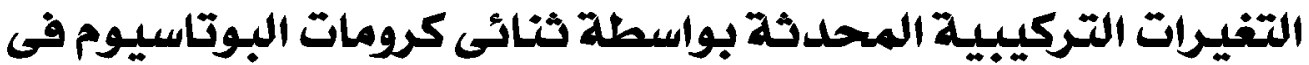

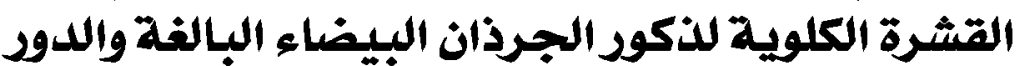

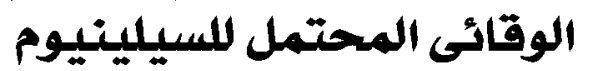

خلفية البحث: ثنائى كرومات البوتاسيوم هو مادة شائعة الوجود في البيئة وأعتبرت فى الآونة الآخيرة كواحدة من المواد المسرطنة مما أكسبها الكثير من الأهتمام البيئى والبحثى البونائ.

الهدف من العمل: هو إلقاء الضوء على التغيرات التى قد تحدث فى القشرة الكلوية لذكود الجرذان البيضاء البالفة نتيجة التعرض لمادة

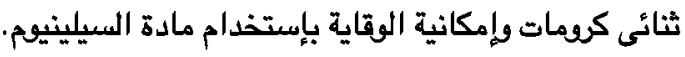

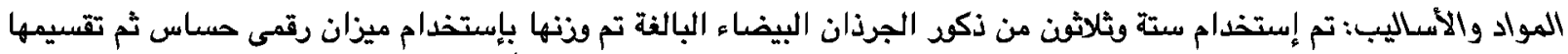

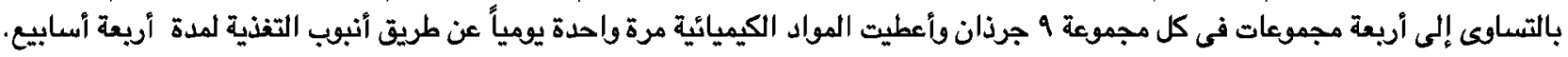
المجموعة الأولى : لم تتلقى أى علاج تم إعتبارها مجموعة ضابطة

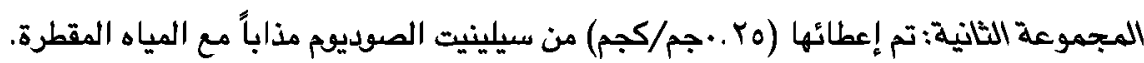

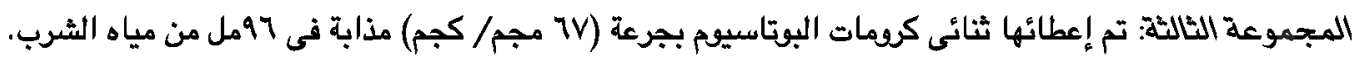

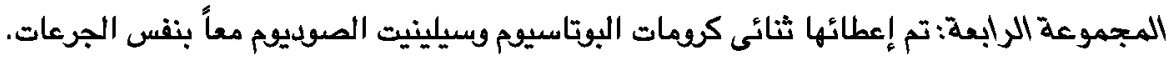

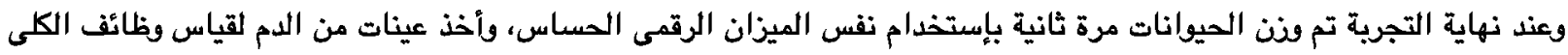

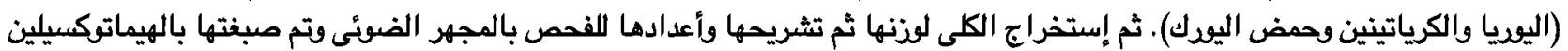

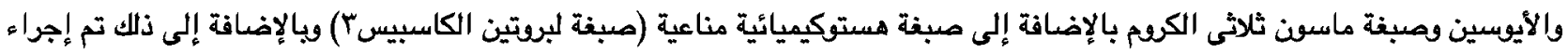
التحليل الموفومترى والإحصائى.

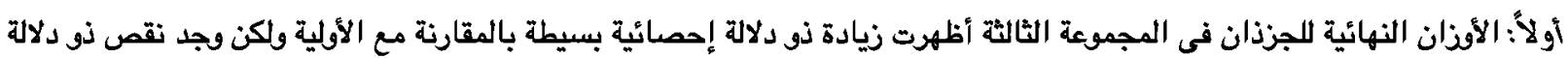

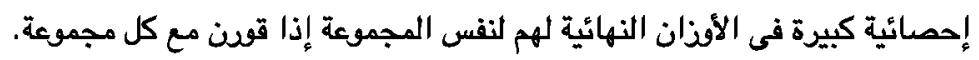

كانيا: كما أظهرت نتائج قياس الكرياتتين واليوريا وحمض اليوريك فى الدم أن هناك زيادة كبيرة فى مستوى كل منهما فى المجموعة المعالجة

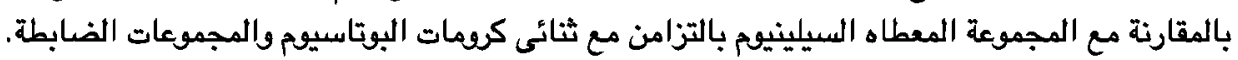

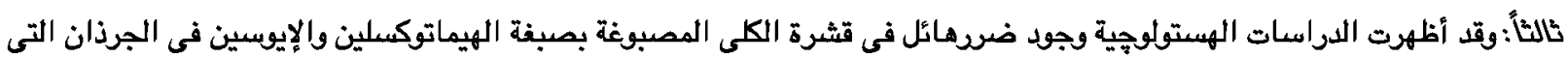
عولجت بثنائى كرومات البوتاسيوم عن طريق الفم والتى شملت المحفظة الكلوية والنسيج الكلى الكى الداخلى.

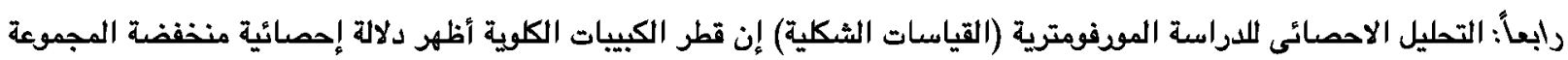

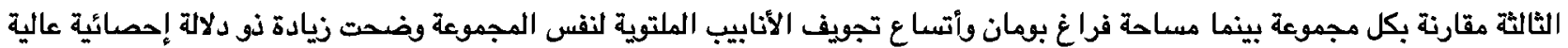
مقارنة بكل مجموعة.

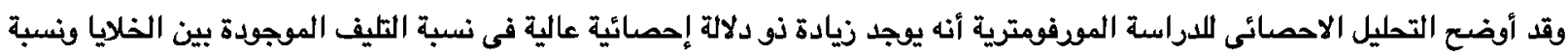

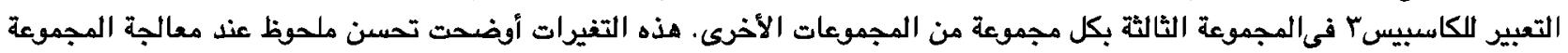

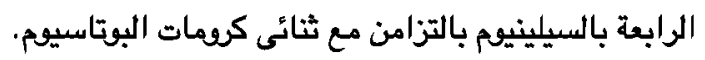

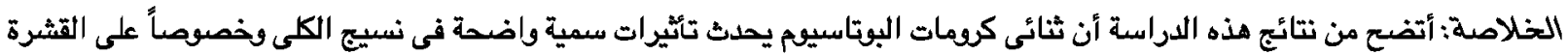

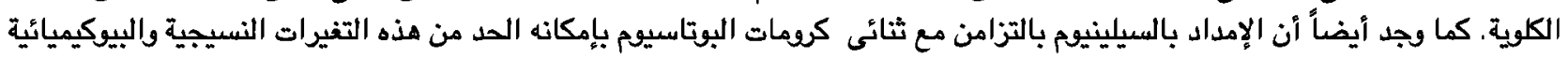

